MATEC Web of Conferences 34, 06007 (2015)

DOI: $10.1051 /$ matecconf/ 20153406007

(C) Owned by the authors, published by EDP Sciences, 2015

\title{
Hardware in the loop simulation test platform of fuel cell backup system
}

\author{
Ma Tiancai, Wang Fuxian ${ }^{a}$, Xu Shi, Zhu Dong, Dai Yuanxing and Gu Rongxin
}

Clean Energy Automotive Engineering Center, Tongji University, China

\begin{abstract}
Based on an analysis of voltage mechanistic model, a real-time simulation model of the proton exchange membrane (PEM) fuel cell backup system is developed, and verified by the measurable experiment data. The method of online parameters identification for the model is also improved. Based on the software LabVIEW/VeriStand real-time environment and the PXI Express hardware system, the PEM fuel cell system controller hardware in the loop (HIL) simulation plat-form is established. Controller simulation test results showed the accuracy of HIL simulation platform.
\end{abstract}

The proton exchange membrane (PEM) fuel cell has broad application prospects, based on its clean, efficient advantages, but at present its reliability and durability are the key barriers for its commercialization. The reliability and durability can be improved through a lot of system test for improvement of auxiliary system matching and control strategy, which however causes the high cost, and has the risk of damaging the fuel cell stack and auxiliary system. Hardware in the loop (HIL) real-time simulation platform can simulate the system extreme conditions, rapidly detect control strategy, forming a cheap capability of testing PEM fuel cell auxiliary system and rapid control strategy optimization.

To the best of our knowledge, we found that the main methods of HIL simulation test platform were combined simulation models based on Matlab/Simulink software with $\mathrm{x}-\mathrm{PC}[1-2]$ or dSPACE real-time[3] hardware system. But, communication between $\mathrm{x}$ - PC real-time system and tested ECU needs to design signal processing hardware; dSPACE real-time system is more expensive, while PXI Express real-time system has a high speed computing capability, and is equipped with abundant I/O and signal processing units, etc. The Labview/VeriStand is a realtime test application software, convenient to import simulation model and control algorithm from the Simulink software environment.

HIL simulation test needs a suitable system dynamic model, but the most of present PEM fuel cell mathematical models are based on mechanistic approaches [4] and empirical approaches [5-6]. However mechanistic models generally require highly the knowledge of fuel cell stack internal parameters; empirical models are combined with mechanistic and empirical formulas [7], its voltage parameters are obtained by the experimental data, but the model parameters are not accurate for different fuel cell system. For different system of PEMFC, its mechanistic model and empirical model are obtained by parameter identification [8-9] based on experimental data. The specific definition of PEM fuel cell modeling parameters and the parameter identification process are rarely studied. Therefore, combining with stack voltage mechanistic formula, we established the PEM fuel cell backup system dynamic model, and showed specific measured input parameters definition and the model parameters identification. Based on the VeriStand real-time software and PXI Express hardware system, PEM fuel cell HIL simulation platform was developed and the PEMFC system hardware in the loop simulation test was implemented. Simulation test platform results showed the accuracy of HIL simulation model. It could perform various tests on verification of low-level software platform and high-level control algorithms.

\section{PEM fuel cell backup simulation model}

\subsection{System description}

When the grid is interrupted, the PEM fuel cell backup supplies power for communication base station electricity equipment; while the power recoveries the backup system enters into the standby mode. The system includes fuel cell stack, air supply, hydrogen and cooling subsystem (Figure.1). The blower supplies air humidified by the exhausted cathode gas; the system controls the blower open value to meet the need of air supply at the condition of different loads. The hydrogen is supplied by compressed hydrogen tank. The cooling subsystem includes the cooling water pump, radiator, radiator fan, water tank, normally open (NO) and normally close (NC) solenoid valve, and the coolant is deionized water.

\footnotetext{
a Wang Fuxian: wangfuxian01@163.com
} 


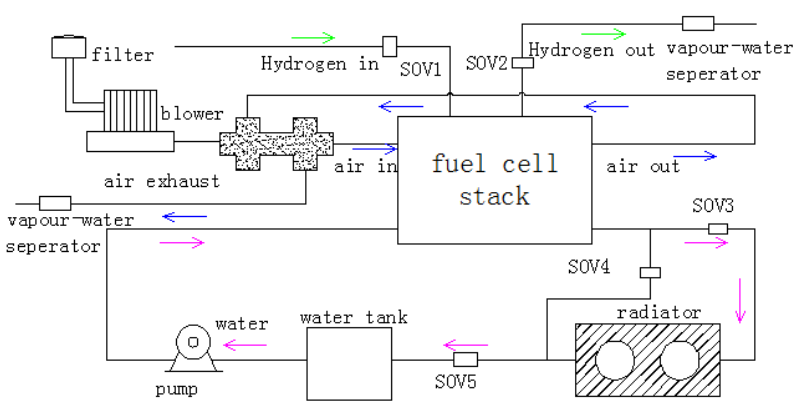

Figure 1. Fuel cell backup system structure

\subsection{Simulation model}

HIL simulation test platform is to test the controller robustness and optimize control algorithms, thus, the simulation model should meet the need of the precision and real-time performance. We consider the stack, fluid dynamic performance of the simulation to detect the response time and robustness of controller. Therefore, the PEM fuel cell stack, cathode flow performance, cooling system models were established.

\subsubsection{Stack model}

PEM fuel cell stack output voltage mechanical model can be expressed

$$
\begin{aligned}
E_{\text {cell }}= & E_{\text {Nernst }}+\eta_{\text {act }}+\eta_{\text {ohmic }} \\
E_{\text {Nernst }}= & 1.229-0.85 \times 10^{-3}\left(T_{s t}-298.15\right) \\
& +4.301 \times 10^{-5} T_{s t} \ln \left(p_{H_{2}}^{*}\left(p_{O_{2}}^{*}\right)^{0.5}\right) \\
\eta_{\text {act }}=\xi_{1} & +\xi_{2} T_{s t}+\xi_{3} T_{s t} \ln I_{s t}+\xi_{4} T_{s t} \ln c_{O_{2}}^{*} \\
\eta_{\text {ohmic }}= & -I \times R_{\text {internal }}=-I_{s t}\left(\xi_{5}+\xi_{6} T_{\text {st }}+\xi_{7} I_{\text {st }}\right)
\end{aligned}
$$

Though the gas flow channels, the porous electrodes, the water film and the catalyst surface, the three mass transport interfaces, the effective reactant partial value and the concentration of species at catalyst surface were defined as [6]

$$
\begin{aligned}
& p_{O_{2}}^{*}=p_{c a}-p_{c a, v a p}-p_{N_{2}}^{*} \\
&= p_{c a}-\phi_{c a} p_{c a, s a t}-p_{N_{2}} \exp \left(0.296 \cdot i / T_{s t}^{0.832}\right) \\
& p_{H_{2}}^{*}= \frac{p_{a n}}{\exp \left(1.334 \cdot i / T_{s t}^{1.334}\right)}-\phi_{a n} p_{a n, s a t} \\
& c_{O_{2}}^{*}= \frac{p_{O_{2}}^{*}}{5.08 \cdot 10^{6} \exp \left(-498 / T_{s t}\right)} \\
& \log _{10} p_{s a t}=-2.1794+0.02953 T \\
& \quad-9.1837 \cdot 10^{-5} T^{2}+1.4454 \cdot 10^{-7} T^{3}
\end{aligned}
$$

The PEM fuel cell system parameters are different due to the different system structure and material. The parameters identification method based on the measured test data is used to improve the model precision and HIL simulation platform robustness. The actual stack open circle voltage was calculated by on-line parameters identification

$$
\begin{aligned}
E_{o c}= & 1.155-6.263 \times 10^{-3}\left(T_{s t}-298.15\right) \\
& +2.275 \times 10^{-5} T_{s t} \ln \left(P_{H_{2}}^{*}\left(P_{O_{2}}^{*}\right)^{0.5}\right)
\end{aligned}
$$

So, combining Eqs. 1-3 can yield the fuel cell system output voltage

$$
\begin{aligned}
E_{s t}= & E_{o c}+\xi_{1}+\xi_{2} T+\xi_{3} T_{s t} \ln I_{s t}+\xi_{4} T_{s t} \ln c_{O_{2}}^{*} \\
& -I_{s t}\left(\xi_{5}+\xi_{6} T_{s t}+\xi_{7} I_{s t}\right)
\end{aligned}
$$

So, Eq. 4 can be expressed

$$
\begin{aligned}
& K \cdot \xi=E \\
& K=\left[\begin{array}{llllll}
k_{11} & k_{12} & \cdots & \cdots & k_{16} & k_{17} \\
\cdots & \cdots & \cdots & \cdots & \cdots & \cdots \\
k_{n 1} & k_{n 2} & \cdots & \cdots & k_{n 6} & k_{n 7}
\end{array}\right] \\
& \xi=\left[\begin{array}{lllllll}
\xi_{1} & \xi_{2} & \xi_{3} & \xi_{4} & \xi_{5} & \xi_{6} & \xi_{7}
\end{array}\right]^{T} \\
& E=\left[\begin{array}{llll}
E_{s t 1} & \cdots & \cdots & E_{s t n}
\end{array}\right]^{T}
\end{aligned}
$$

The model parameters were achieved by on-line parameters identification (table 1).

Table 1. Fuel cell voltage parameters

\begin{tabular}{|c|c|c|c|c|c|c|c|}
\hline Parameter & $\xi_{1}$ & $\xi_{2}$ & $\xi_{3}$ & $\xi_{4}$ & $\xi_{5}$ & $\xi_{6}$ & $\xi_{7}$ \\
\hline Value & -2.5521 & 0.0118 & 0.000279 & $-7.422 \mathrm{e}-5$ & 0.00242 & $-4.351 \mathrm{e}-6$ & $2.563 \mathrm{e}-7$ \\
\hline
\end{tabular}

\subsubsection{Cathode fluid characteristic model}

The cathode system includes the blower, humidifier, stack flow channel, gas pipes, etc. The stack flow can be equivalent to a nozzle and the air in stack flow is the mixture condition of the laminar and turbulent condition, so the relation between cathode air mass flow rate and the flow resistance in stack (or supply pipe) can be expressed as

$$
\begin{aligned}
\dot{m}_{c a, \text { avg }}= & k_{c a, v 1}\left(p_{c a, \text { in }}-p_{c a, \text { out }}\right) \\
& +k_{c a, v 2} \sqrt{p_{c a, \text { in }}-p_{c a, \text { out }}}
\end{aligned}
$$


The relation among the blower open value, outlet flow, pressure can be obtained by testing its MAP curve. At the normal load condition, the anode hydrogen properties are similar with the cathode properties, so which is not mentioned again.

\subsubsection{Cooling system model}

The fuel cell stack temperature can be kept in the normal operating range through the cooling water pump dissipating heat generated by electrochemical reaction in the stack[10-11]. We assume the stack is an opening energy system, and the energy into the system is the thermodynamic and chemical energy of the reactant, excess gas and cooling water; the energy out the system is the electric power by the stack, cooling water heat, and the energy taken away by the reactant not involved.

We ignore the conduction and radiation heat from the stack surface into the environment; so we mainly consider the heat generated by the electrochemical reaction and the heat taken away by the cooling system.

The added energy is the stack energy increment, i.e., the change of stack temperature, so the stack temperature model can be describe

$$
\begin{aligned}
& \dot{Q}_{g e n}=I_{s t}\left(n_{c e l l} E_{e q u, H H V}-E_{s t}\right) \\
& \dot{Q}_{c w}=C_{c w} \dot{m}_{c w}\left(T_{c w, i n}-T_{c w, o u t}\right) \\
& \dot{Q}_{s t}=\dot{Q}_{g e n}+\dot{Q}_{c w}=C_{s t} m_{s t} \frac{d T_{s t}}{d t} \\
& T_{s t}=\left(T_{c w, o u t}+T_{c w, i n}\right) / 2
\end{aligned}
$$

The backup system temperature control method mainly controls the radiator fan opening value according to the cooling water inlet and outlet temperature. The relation among the radiator cooling capacity, radiator fan opening value and cooling water inlet and outlet temperature can be got by the test at the different output power and cooling water flow rate. The radiator model can be yielded by test data fitting

$$
\begin{aligned}
\dot{Q}_{\text {rad }} & =f\left(n_{f a n}, T_{a m b}, T_{c w, \text { out }}\right) \\
& =C_{c w} \dot{m}_{c w}\left(T_{c w, o u t}-T_{c w, \text { in }}\right)
\end{aligned}
$$

\subsection{Model validation}

The models above input data can be all measured, and the models are simulated in the MATLAB/Simulink. The experimental data and model simulation are compared at the steady and dynamic condition separately. The steady test output voltage and model voltage data are plotted in Figure. 2 at the condition that cooling inlet water is $55^{\circ} \mathrm{C}$, air inlet pressure $0.07 \mathrm{bar}$, and hydrogen inlet pressure $0.6 \mathrm{bar}$. The output voltage dynamic response is shown in Figure. 3.

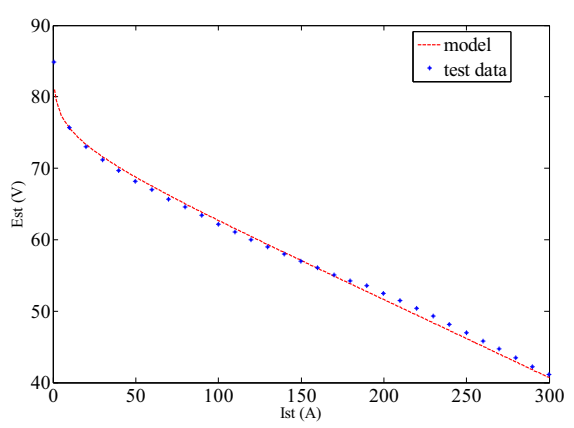

Figure 2. Fuel cell sack polarization curve

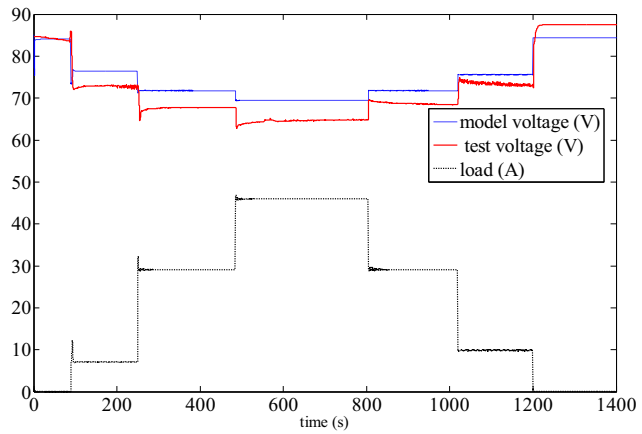

Figure 3. Fuel cell system dynamic response

The simulation result (Figure. 2) shows that PEM fuel cell stack output voltage error is less $3 \%$, which is HIL test accuracy. The PEM fuel cell system dynamic voltage responds quickly with the load and the error is less $5 \%$, which improves the controller robustness.

\section{HIL simulation test}

\subsection{HIL test platform framework}

Figure. 4 shows HIL test platform framework, including the PEM fuel cell simulation system, signal receiving and processing system and real-time monitor system.

The PEM fuel cell simulation system includes the simulation models and model operating interface. The modes are running in LabVIEW/VeriStand software on a PXI Express controller. The model operating interface developed by the VeriStand shows the main dynamic parameters, which can configure the load, event alarm; recording test data, and generating the test report automatically. The single cell voltage monitor module (CVM), the tested system controller, DC-DC module, real-time monitor system communicate by the CAN .

The signal receiving and processing system includes PXI Express controller and PXI board receiving and processing analogy, digital, CAN signal. PXI Express hardware system has the real-time processor, I/O connector, and fault insertion unit (FIU), load simulation unit, signal processing unit, etc. The simulation model signal can be transformed to the actual physical signal, which keeps the message between system model and the tested controller in accordance with actual system.

The real-time monitor system shows all controller state parameter, which is also developed by the VeriStand software. 


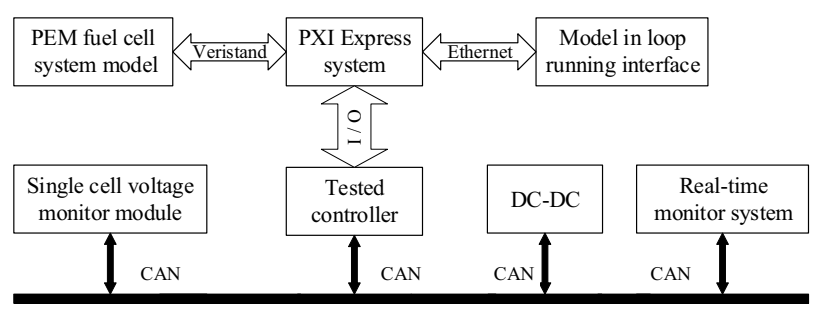

Figure 4. HIL simulation test platform framework

HIL simulation test can be divided into two steps, model in the loop and hardware in the loop (Figure. 5). The Simulink fuel cell system model is integrated with VeriStand by compiling the Simulink model into a DLL and calling it from the VeriStand system explorer, which is called model in the loop (MIL) real-time simulation. Then, the controller is replaced with the tested controller, forming the hardware in the loop by mapping the model in and out parameter with PXI I/O ports.

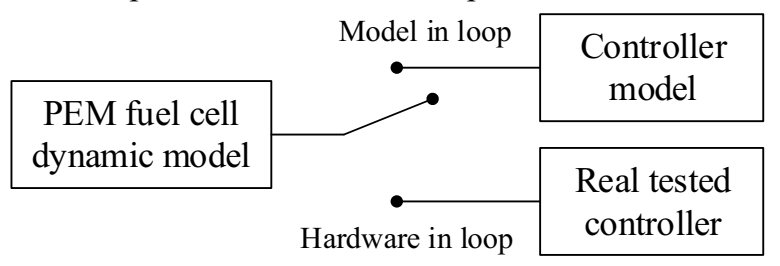

Figure 5. MIL simulation and HIL test

\subsection{Fuel cell system MIL}

The fuel cell system model is compiled by Simulink, then running in VeriStand real-time environment in the PXI Express. We configured the fuel cell system load and edited the operation interface.

The fuel cell model of the whole system is divided into controller model (Figure. 6) and the system model (Figure. 7). The fuel cell system Simulink models are connected with software VeriStand by VeriStand in and VeriStand out, then, compiled in VeriStand environment[12]. The whole system model in the loop is completed by mapping controller model and system model I/O ports. Then we create a test excitation signal, generating the load.

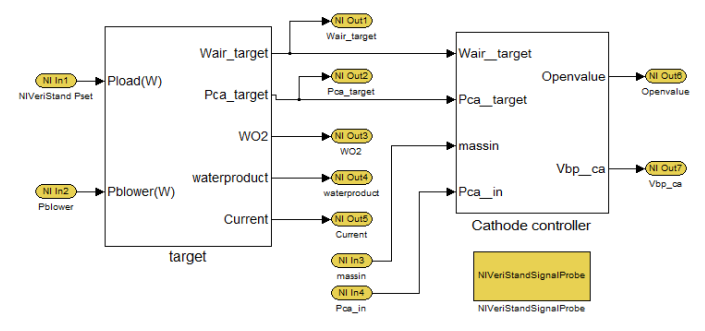

Figure 6. Controller model

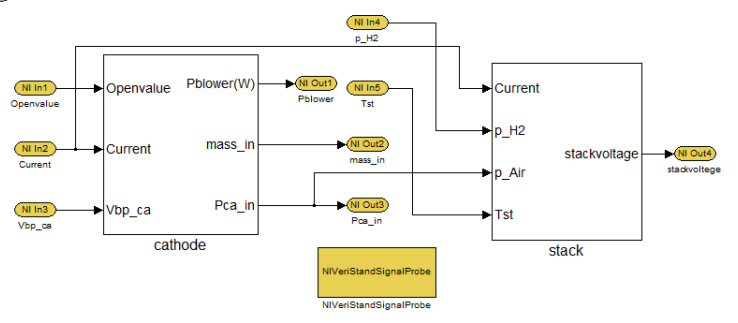

\subsection{Simulation test}

The PXI Express I/O resource was allocated to transform simulation model signals to the actual physical signal (table 2). The hardware resource allocation provides a good interface configuration for the data exchange between the HIL test platform and tested controller, convenient to realize the controller control strategy optimization and the auxiliary system matching study.

Table 2. System signal definition and PXI I/O allocation

\begin{tabular}{|c|c|c|c|}
\hline Signal name & Signal type & $\begin{array}{c}\text { Board } \\
\text { name }\end{array}$ & $\mathrm{I} / \mathrm{O}$ \\
\hline $\begin{array}{c}\text { radiator fan } \\
\text { opening value }\end{array}$ & analog input & 6225 & $\mathrm{AI} 0$ \\
\hline $\begin{array}{c}\text { blower opening } \\
\text { value }\end{array}$ & analog input & 6225 & AI1 \\
\hline $\begin{array}{c}\text { cooling water NO } \\
\text { valve }\end{array}$ & digital input & 6225 & $\mathrm{P} 1.0$ \\
\hline $\begin{array}{c}\text { cooling water } \mathrm{NC} \\
\text { valve } \\
\end{array}$ & digital input & 6225 & P1.1 \\
\hline water pump relay & digital input & 6225 & $\mathrm{P} 1.2$ \\
\hline heater relay & digital input & 6225 & $\mathrm{P} 1.3$ \\
\hline $\begin{array}{l}\text { h2 inlet solenoid } \\
\text { valve }\end{array}$ & digital input & 6225 & $\mathrm{P} 1.4$ \\
\hline $\begin{array}{c}\text { h2 outlet solenoid } \\
\text { valve }\end{array}$ & digital input & 6225 & $\mathrm{P} 1.5$ \\
\hline h2 main valve & digital input & 6225 & P1.6 \\
\hline cabinet fan & digital input & 6225 & $\mathrm{P} 1.7$ \\
\hline $\begin{array}{l}\text { operation } \\
\text { indicator }\end{array}$ & digital input & 6225 & $\mathrm{P} 1.8$ \\
\hline $\begin{array}{c}\text { fault indicator } \\
\text { \&buzzer }\end{array}$ & digital input & 6225 & P1.9 \\
\hline $\begin{array}{l}\text { cooling water } \\
\text { inlet pressure }\end{array}$ & analog output & 6704 & $\mathrm{AO} 1$ \\
\hline $\mathrm{h} 2$ inlet pressure & analog output & 6704 & $\mathrm{AO} 2$ \\
\hline air inlet pressure & analog output & 6704 & $\mathrm{AO} 3$ \\
\hline $\begin{array}{l}\text { main } \mathrm{h} 2 \text { tank } \\
\text { pressure }\end{array}$ & analog output & 6704 & $\mathrm{AO} 4$ \\
\hline $\begin{array}{l}\text { system house h2 } \\
\text { concentration }\end{array}$ & analog output & 6704 & $\mathrm{AO5}$ \\
\hline $\begin{array}{c}\mathrm{h} 2 \text { house } \\
\text { concentration }\end{array}$ & analog output & 6704 & AO6 \\
\hline stack voltage & analog output & 6704 & $\mathrm{AO} 7$ \\
\hline load voltage & analog output & 6704 & $\mathrm{AO} 8$ \\
\hline load current & analog output & 6704 & AO9 \\
\hline stack current & analog output & 6704 & AO10 \\
\hline $\begin{array}{l}\text { water tank high } \\
\text { water switch }\end{array}$ & digital output & 6704 & P 0.0 \\
\hline $\begin{array}{c}\text { water tank low } \\
\text { water switch }\end{array}$ & digital output & 6704 & P0.1 \\
\hline $\begin{array}{l}\text { cabinet entrance } \\
\text { guard switch }\end{array}$ & digital output & 6704 & $\mathrm{P} 0.2$ \\
\hline stack contactor & digital output & 6704 & P0.3 \\
\hline power load & analog input & 66106A & \\
\hline DCDC & CAN & $8513 / 2$ & CANO \\
\hline CVM & CAN & $8513 / 2$ & CAN1 \\
\hline FIU & digital input & 2510 & \\
\hline
\end{tabular}

Figure 7. System model 
The hardware and software of fuel cell backup system controller were tested on the HIL simulation test platform. The procedure is that controller is connected with test platform I/O, then running system simulation model, and starting the real-time monitoring system.

The accuracy of simulation model and control algorithm robustness were tested through simulating the base station load, and the controller parameters are preliminary optimized and calibrated, etc. After system controller simulation platform was repeated tests, the actual system experiment was carried out(Figure. 8), where the data obtained from the experiment is helpful for simulation model for further accurate matching calibration, so that simulation platform conforms to the actual system.
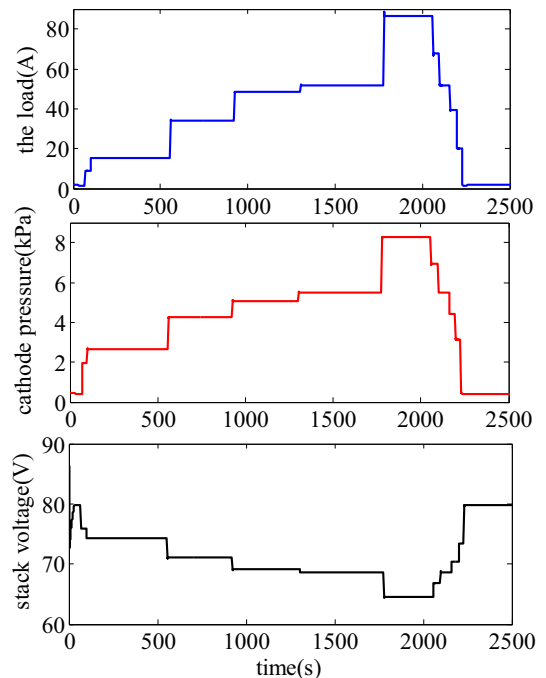

Figure 8. HIL test result

\section{Conclusion}

We developed a real-time simulation model of the PEM fuel cell backup system on basis of an analysis of voltage mechanistic model. The very good agreement between the simulation and experimental data indicates that the method is simple and effective, all input parameter clearly defined, based on the measured experimental data. Based on NI VeriStand real-time software environment and PXI Express hardware resources, the HIL simulation platform framework was built, including fuel cell simulation system, signal receiving and processing system and real-time monitoring system. After model in the loop in VeriStand real-time environment and allocation of PXI hardware I/O, the actual controller HIL simulation test was completed. The controller was tested with actual backup system, which further improves the accuracy of the HIL simulation platform.

\section{Acknowledgments}

This work was supported by state 863 project: fuel cell backup reliability and durability key technology study (2013AA051001).

\section{Appendix}

List of symbols

$E_{\text {cell }} \quad$ single cell voltage, $\mathrm{V}$

$E_{\text {Nernst }}$ open voltage, $\mathrm{V}$

$\eta_{\text {act }} \quad$ overvoltage due to activation, $\mathrm{V}$

$\eta_{\text {ohmic }} \quad$ overvoltage due to ohmic resistance, $\mathrm{V}$

$T_{s t} \quad$ stack temperature, $\mathrm{K}$

$T_{c w, i n} \quad$ cooling water inlet temperature, $\mathrm{K}$

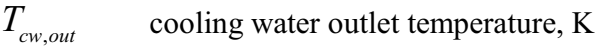

$p_{i} \quad$ absolute pressure of component $\mathrm{i}$, bar

$p_{i}^{*} \quad$ partial pressure of component $i$ at catalyst surface, bar

$p_{i, s a t} \quad$ saturated vapor pressure of component $\mathrm{i}$, bar

$c_{\mathrm{O}_{2}}^{*} \quad$ concentration of species at catalyst surface, $\mathrm{mol} / \mathrm{cm}^{3}$

$I_{s t} \quad$ stack current, A

$i \quad$ stack current density, $\mathrm{A} / \mathrm{cm}^{2}$

$\phi_{i} \quad$ relative humidity of component i, \%

$\dot{m}_{c a, a v g} \quad$ average wet air mass flow rate in the stack, $\mathrm{g} / \mathrm{s}$

$k_{c a, v i} \quad$ equivalent nozzle coefficient

$p_{\text {ca,out }} \quad$ cathode outlet pressure, bar

$\dot{Q}_{\text {gen }} \quad$ electrochemical heat generated in the stack, W

$\dot{Q}_{c w} \quad$ the energy effect of cooling water, W

$\dot{Q}_{s t} \quad$ the change of stack thermodynamic energy, W

$E_{e q u, H H V} \quad$ high heat equivalent voltage, $1.48 \mathrm{~V}$

$\dot{m}_{c w} \quad$ cooling water mass flow rate, $\mathrm{g} / \mathrm{s}$

$C_{c w} \quad$ cooling water capacity at constant pressure, $\mathrm{J} /(\mathrm{g})(\mathrm{K})$

$C_{s t} \quad$ average stack capacity, $\mathrm{J} /(\mathrm{g})(\mathrm{K})$

$m_{s t} \quad$ stack mass, $\mathrm{g}$

h2 hydrogen

\section{References}

1. He Bin, Hua Jianfeng, Li Jianqiu, et al. Study on Simulation Test Platform of Vehicle System Controller for Fuel Cell Vehicle. Journal of system simulation, 7, 17(2007): 1694-1698

2. Hua Jianfeng, He Bin, Zhang Jianyong, et al. Design on HIL Real-time Simulation Test Platform of Vehicle System Controller for Fuel Cell Vehicle. Automotive electronics, 4(2007): 8-11

3. He Bin, Kuang zhibin, Cao Jianwen, et al. HIL simulation of fuel cell vehicle powertrain system. Automotive electronics, 20, 10(2004): 75-76 
4. T. E. Springer, T. A. Zawodzinski, S. Gottesfeld. Polymer Electrolyte Fuel Cell Model. This Journal, 138, 8(1991): 2334

5. J. C. Amphlett, R. M. Baumert, R. F. Mann, et al. Parametric modeling of the performance of a $5-\mathrm{kW}$ proton-exchange membrane fuel cell stack. J. Power Sources, 49(1994): 349-356

6. J. C. Amphlett, R. M. Baumert, R. F. Mann, et al. Performance modeling of the Ballard Mark IV solid polymer electrolyte fuel cell I. Mechanistic model development. J. Electrochem. Soc. 142, 1(1995) : 1-8

7. J. C. Amphlett, R. M. Baumert, R. F. Mann, et al. Performance modeling of the Ballard Mark IV solid polymer electrolyte fuel cell II. Empirical model development. J. Electrochem. Soc. 142, 1(1995): 915

8. Gao kunpeng, Zhang tong, Huang chendong, et al. Modeling and Simulation of a 45 KW Proton Exchange Membrane Fuel Cell Engine. Journal of Tongji University, 41, 2(2013): 264-270

9. Zhou Su, Zhang Chuansheng, Chen Fengxiang. Modeling and Simulation of High-pressure Automobile PEMFC Power System. Journal of system simulation, 23, 7(2011):1469-1476

10. Ma tiancai. Fuel cell engine control-system analysis and simulation. Tongji University, (2007)

11. Gu Jing, Lu Languang, Ouyang Minggao. Thermal management subsystem model and temperature control for fuel cells. Journal of Tsinghua University (Science \&Technology), 47, 11(2007): 2036-2039.

12. http://www.ni.com/veristand/whatis/zhs/ 